International Journal of Instruction e-ISSN: 1308-1470 • www.e-iji.net

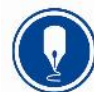

January $2022 \bullet$ Vol.15, No.1

p-ISSN: 1694-609X

pp. 653-672

Article submission code:

20210316151110
Received: 16/03/2021

Revision: 25/07/2021
Accepted: 17/08/2021

OnlineFirst: 08/11/2021

\title{
Motives, Self-Regulation, and Spiritual Experiences of Hafizh (The Qur'an Memorizer) in Indonesia
}

\section{Eva Latipah}

Dr., Faculty of Tarbiyah and Education, Universitas Islam Negeri Sunan Kalijaga, Indonesia,eva.latipah@uin-suka.ac.id

This phenomenological study aims to examine the motives of the hafizh (The Qur'an memorizer), the self-regulation of the hafizh, and the spiritual experiences of the hafizh. The participants of this research were 10 students who had memorized the Qur'an at least 15 juz (chapter). Data collection was carried out by in-depth interviews and observations. Data analysis was carried out by taking the data, organizing the data, sorting the data, synthesizing data, looking for and finding patterns, and testing the validity of the data through triangulation techniques and dependability tests. The results showed that the hafizh motive consists of motives which include a strong desire to memorize the Qur'an, a strong desire to deepen the knowledge of religion, belief in increasing the degree of science, and belief in preserving the Qur'an. Its extrinsic motives include being inspired by the good behaviour of parents as a hafizh, investing in family life, investing in the afterlife, and solutions to life problems. Self-regulation that is carried out includes strengthening the intention to memorize the Qur'an, understanding the stages of tahfizh (memorizing the Qur'an), setting targets per day, choosing the ideal time to memorize the Qur'an, choosing a comfortable place to memorize, having a strategy of maintaining memorization. The spiritual experiences of hafizh include feeling calm, getting help during difficulties, especially in completing college assignments, feeling awake, and feeling peaceful. The results of this study are expected to be a simple guide for other prospective Qur'an practitioners.

Keywords: extrinsic motivation, intrinsic motivation, motive, Quran memorizer, selfregulation, spiritual experience

\section{INTRODUCTION}

Indonesia is a country with the highest Muslim population in the world. Recent data shows that 229 million Muslims are in Indonesia, 87.2\% of Indonesia's population of 263 million, or around 13\% of the world's Muslim population (Mietzner \& Muhtadi, 2018). With such a large Muslim population, it is not surprising that most Indonesians have a high interest in memorizing the Qur'an, considering that memorizing the Qur'an has many virtues. The Qur'an is a guide in human life. The Qur'an is the holy book that was revealed by Allah to the Prophet Muhammad as a guide as well as a complement to

Citation: Latipah, E. (2022). Motives, self-regulation, and spiritual experiences of hafizh (The Qur'an memorizer) in Indonesia. International Journal of Instruction, 15(1), 653-672. https://doi.org/10.29333/iji.2022.15137a 
the previous scriptures. The Qur'an is guarded by Allah from all forms of deviation and change (addition and subtraction). As stated in the Q.S. Al-Hijr verse "Behold, we are the ones who sent down the Qur'an, and indeed we take care of it". This is the guarantee of Allah for the Qur'an. This does not mean that every Muslim is free from the responsibility and obligation to maintain the purity of the Qur'an. In keeping the Qur'an Allah involves his servants (Ali, 2011). The form of this involvement is by memorizing the Qur'an.

Memorizing the Qur'an has been done since the time of Prophet Muhammad, even by the Prophet himself when he received the Qur'anic verses as revelations from the angel Jibril. Every time he received a revelation, the Prophet Muhammad memorized it immediately because the Prophet Muhammad at that time was in people state that could not read or write. If a verse or surah was revealed, then immediately the Prophet Muhammad memorized it, then taught it to the companions and asked them to memorize it. They repeatedly recited the verse or surah before the Prophet Muhammad. When there was a war that caused many of the companions who memorized the Quran during the Caliphate of Abu Bakr As Sidiq, Umar's companions were suggested to write it into a book so that the Qur'an would not be lost along with its memorizers (Ali, 2011).

The Quraish Shihab said that although the Prophet Muhammad and his companions memorized the verses of the Qur'an, to ensure the preservation of divine revelations. The Prophet Muhammad did not only rely on memorization but also writing. History informs that every time a verse has come down, the Prophet Muhammad then called his friends who were known to be good at writing, to write down the verses he had just received while conveying the place and order of each verse in his surah. They wrote these verses in date palm leaves, stones, animal skins, or bones. Some of the companions also wrote these verses privately, but due to their limited writing instruments and abilities, not many did it, and most likely did not cover all the verses of the Qur'an. The pieces of written manuscripts ordered by the Prophet were only compiled in the form of books at the time of the Caliph Abu Bakr (Quraish, 1994).

The development of memorizing the Qur'an in Indonesia today is shown, for one thing, by the spread of little hafizh (The Qur'an memorizer) starting from the age of 3 years. Even the memorization of the Qur'an is broadcast on a prestigious private television station in Indonesia. Likewise, adults who are currently pursuing higher education do not want to be left behind to enliven the memorization of the Qur'an. However, the memorizers of the Qur'an certainly need to control themselves so that their memorization lasts a long time or can even increase memorization. Self-control activities or also called self-regulation skills are closely related to regulating emotions and behavior in any situation that can be done by memorizing the Qur'an independently (Nigg, 2017). The Qur'an memorizer must be equipped with self-regulation skills so that it is not easy for a negative mood to appear when memorizing the Qur'an in the hope that they will be able to memorize the Qur'an in sad or happy conditions. In addition, selfregulation skills are also able to strengthen the personality of the memorizers of the Koran so that they can practice the contents of the Koran that they memorize in their daily lives (Huda et al., 2019). The Qur'an memorizers in strengthening self-regulation 
skills need to be carried out continuously while still paying attention to the virtues of memorizing the Qur'an. Someone who has good self-regulation skills is certainly able to optimize his memory to memorize the Qur'an. In addition to getting a reward from Allah, memorizing the Qur'an also has benefits in continuing to study in Indonesia. Interestingly, several tertiary institutions, both state universities under the Ministry of Religion and the Ministry of Education and Culture, gave affirmations in the form of free college entrance tests for prospective students who had achievements in the form of memorizing the Qur'an. Due to this, it is only natural that several Muslims in Indonesia are competing to memorize the Qur'an. That is how Allah involves his servants in maintaining the Qur'an.

Memorizing the Qur'an has become a tradition for several groups with various purposes. At the time the Prophet Muhammad memorized the Qur'an was aimed at preserving the verses of the Qur'an. Currently memorizing the Qur'an is carried out by several people because of its various virtues, such as 1) that memorizing the Qur'an is included in the class of knowledgeable people (Surah Al-Ankabut verses 48-49); 2) memorizing the Qur'an is a source of salvation for the world and the hereafter; 3) memorizing the Qur'an will be saved from the fire of hell (Historical Hadith of Ahmad, in Ahsin, 1994); 4) memorizers of the Qur'an are at the forefront of the world and the hereafter (Historical Hadith of Muslim, in Ahsin, 1994); 4) memorizing the Qur'an gets a high degree in heaven (Historical Hadith of Bukhari Muslim, in Ahsin, 1994); 5) The Qur'an will provide intercession on the day of judgment for those who read, memorize and practice it; and 6) memorizer of the Qur'an will be placed on the head of the crown of honor, and both parents will be dressed in clothes that do not exist in the world (Historical Hadith of Muslim, in Ahsin, 1994).

\section{Literature Review}

\section{Motive}

Every action or action is driven by a motive (Hommel \& Wiers, 2017). Likewise, memorizing the Qur'an occurs because of the encouragement (drives) as a motive. Thus, motive is someone's drive (impulse) to do something (Passer \& Smith, 2004). Motive is also an inner drive that creates, maintains, and directs behavior towards a goal (Latipah \& Kamsyach, 2017). Thus, the motive can determine someone in memorizing the Qur'an. As a motive act, memorizing the Qur'an encourages someone to come up with movements to carry out activities to achieve goals according to their motives (Kibtiyah et al., 2020). The movement to carry out this activity is known as motivation (Ormrod et al., 2006). Motives change to motivation due to stimulation (Passer \& Smith, 2004). If the stimulation comes from within, it is called intrinsic motivation; and if the stimulation comes from outside the self, it is called extrinsic motivation.

Intrinsic motivation is a natural tendency to seek and conquer challenges when pursued by personal interests and implementing capabilities (Wang et al., 2019). A person who memorizes the Qur'an is intrinsically motivated and does not need incentives or punishment because memorizing the Qur'an itself is rewarding, giving him pleasure, helping to develop skills that are deemed important, or appearing to be ethically or 
morally correct to do (Santrock, 2017). Conversely, someone who memorizes the Qur'an is extrinsically motivated, for example wanting praise, appreciation, or recognition for his activities, basically making memorizing the Qur'an a means to an end, not as an end (Ainisyifa \& Amelia, 2018).

A person is often motivated intrinsically and extrinsically simultaneously (Lepper et al., 2005). Thus, it is not so important to dichotomize between internal and external motivation because every activity carried out by a person lies along a continuum, starting from everything determined by oneself to everything determined by others (Larson, 2000). The strength of motivation does not depend on internal or external stimulation. However, the persistence of internal motivation is higher than external motivation. Due to this persistence, many cognitive factors determine internal motivation such as interests, expectations and values, goals, attributions, and lecturers' expectations and attributions (Bilewicz et al., 2017).

\section{Self-Regulation}

Self-regulated skills are individual skills that actively involve metacognition, motivation, and behavior in the learning process. Self-regulated skills are also defined as individual skills related to their learning motivation, autonomously developing measurements (cognition, metacognition, and behavior), and monitoring their learning progress (Oppong et al., 2019). Self-regulated learning emerges as a combination of ability and desire. Individual strategies are planning, controlling, and evaluating cognitive, motivational, behavioral, and contextual processes (Lin, 2018). Everyone knows how to plan is by motivating themselves, knowing their possibilities and limitations, and the process of regulating learning to integrate or combine task objectives and their context to optimize performance and improve skills through practice. Meanwhile, there are ten types of self-regulated cycles that support the independence and self-control of everyone. The ten types of self-regulated skills include mastery self-talk, extrinsic selftalk, relative ability self-talk, relevance enhancement, situational interest enhancement, self-consequating, environment structuring, effort regulation, and time or study environment (Wolters et al., 2005).

Based on the ten types of self-regulated skills, the types of self-regulated skills related to memorizing the Qur'an are extrinsic self-talk, relative ability self-talk, self-consequating, effort regulation, and time or study environment. The Qur'an memorizer needs extrinsic self-talk ability so that the Qur'an memorizer is faced with a desire to finish the memorization process, then the Qur'an memorizer will think of being able to memorize more verses and chapters by improving the reading rules. The memorizers of the Qur'an also need relative self-talk abilities so that they can develop special tips to be able to memorize the Qur'an well and quickly according to their desired goals. In memorizing the Qur'an, each of the memorizers considers the consequences on themselves or selfconsequating. This is done by instilling awareness in each person who memorizes the Qur'an to continue to memorize the Qur'an by paying attention to the consequences. If you memorize the Qur'an according to the rules of reading, many verses, and quickly you will get more rewards from Allah and you will be better able to embellish the Qur'an. If you are lazy to memorize the Qur'an, you will get sin from Allah and losses 
will come. The way that needs to be done by the memorizer of the Qur'an to be able to strengthen and increase his memorization is by strengthening the time or study environment. This is done by managing time and place as effectively as possible in memorizing the Qur'an.

A set of psychological skills called self-regulation largely determines one's memorization of the Qur'an. Self-regulation will condition a person to be disciplined and consistent in memorizing the Qur'an (Albar \& Yuliana, 2021) because self-regulation contains aspects that support a person to be successful in achieving expectations. These aspects include standards and goals set by himself, how to monitor and evaluate his cognitive and behavioral processes, and self-determined consequences for each of his successes and failures (Ormrod et al., 2006). There is very little success for a person to memorize the Qur'an without making standards and goals, without monitoring and evaluation, and without being consequential in his choice.

The standard and purpose of memorizing the Qur'an are made as an initial plan in determining the next step. These standards and goals are in the form of standard short, medium, and long-term goals (Slavin et al., 2009). Standards and short goals, for example, in the form of memorizing targets per day or in one study (memorizing). In a day someone may take the time to memorize the Qur'an two to three times. Standard and medium-term goals, for example in the form of weekly or monthly targets, as well as long-term standards and goals, for example in the form of annual memorization targets.

Standards and goals are made not only in the form of targets but also determine how, how to achieve these short-, medium-, and long-term targets. Regarding how to pursue a target/goal, several methods can be used in memorizing the Qur'an. For example, tasalsuli (memorizing in chains), jam'ii (combining memorization), and muqsam (memorizing by dividing) (Khafidah et al., 2020). The method of tasalsuli (memorizing in chains) is memorizing one page of the Qur'an by memorizing one verse until it is memorized fluently, then moving to the second verse until it is completely smooth, that combine verse 1 with verse 2 without seeing the Qur'an. Do not move to the next verse unless the previous verse is smooth, as well as the third verse to one page, then combines from the first verse to the last.

The jam'ii (combined memorizing) method is memorizing one page of the Qur'an by memorizing one verse until it is smooth, then moving to the second verse, after the second verse smoothly moves to the third verse, and so on up to one page. Then after getting one page memorized, combining the memorization from the first verse to the last without looking at the Qur'an. The muqsam method (memorizing by dividing) is memorizing one page of the Qur'an by dividing it into several parts, each part is memorizing it in tasalsuli (repeating from the beginning) after each part has been perfect (one page) memorized, then put combined from one part to another until all parts can be combined without seeing the Qur'an. This is the middle between the methods tasalsul and jam'ii (Khafidah et al., 2020).

After setting goals and using these methods, a Qur'an memorizer who has selfregulation, monitors and self-evaluates the results obtained, whether the method used in memorizing the Qur'an is to pursue daily weekly, monthly, or even daily targets. He also 
thinks of alternatives if the results of monitoring and evaluation are not as expected. For example, does the memorizer need a quiet and calm atmosphere so that the memorization process feels easy, and memorization can be processed not only into short-term memory but into long-term memory? Therefore, they will usually use a quiet place and time. Quiet places such as mosques are available. For the time usually at night, especially in a third of the night, all of them perform the midnight prayer. Based on the results of interviews with several students and female students who took part in the hafizh (The Qur'an memorizer) program at a boarding school, researchers observed that they had applied self-regulation in memorizing the Qur'an.

If the results (recitation of the Qur'an) are as expected (the goals set), the memorizer of the Qur'an will be consistent in using the methods that have been used. On the other hand, if the results are not as expected, then memorizing the Qur'an will improve the methods that have been used. This is what is called consequent (Ormrod et al., 2006), meaning that memorizers of the Qur'an can sincerely accept every result obtained according to the effort (method) that has been attempted.

\section{Spiritual Experience}

The success of memorizing the Qur'an is also influenced by spiritual experiences, namely the perception of spirituality which involves two things, namely the perception of the existence of something transcendent in everyday life and the perception of involvement with transcendent events in everyday life (Underwood \& Teresi, 2002). The Qur'an memorizer who perceives that there is something transcendent when he is memorizing the Qur'an or perceives that he is involved in transcendent events becomes the driving force for him to memorize the Qur'an.

\section{Research Problems}

Self-regulated learning is a model of a person's ability to manage mastery of the material that has been obtained, mature emotional management, and skills in carrying out a given activity or task. Not only in the school education process but the ability of self-regulated learning is also needed for a memorizer of the Qur'an. The Qur'an memorizer has a special target, namely being able to devour thousands of verses of the Qur'an. This certainly puts a heavy burden on memorizing the Qur'an from a psychological and physical aspect. The mental aspect of a memorizer of the Qur'an needs to have good emotional and psychological abilities. Besides, they are also required to have physical strength because they are required to memorize for a long duration. Several aspects that support and hinder memorizing the Qur'an are very interesting to study more deeply. The experience of each memorizer and the events experienced becomes interesting, new, and unique fit to be researched. Not only seeing the results that have been obtained but also knowing about the process experienced by memorizers of the Qur'an.

\section{Research Question}

Regarding this problem, it is interesting and important to research, what is the real motive of these Qur'an reciters? How do Qur'an memorizers carry out self-regulation while on the other hand, these Qur'an memorizers are also students? Do Qur'an memorizers have any spiritual experiences while memorizing the Quran? 


\section{Research Focus}

This research focuses on three things, namely the motive of memorizing the Qur'an, selfregulation of the Qur'an reciter, and the spiritual experience of memorizing the Qur'an.

\section{METHOD}

\section{General Background}

This research is a qualitative study using a phenomenological approach, which examines the phenomenon of memorizing the Qur'an in terms of motives, self-regulation, and spiritual experiences, by conducting interviews and observations as the main method.

\section{Participants}

The subjects in this study were 10 students, 6 males and 4 females. The number of participants involved in this study was 10 students because exploratory phenomena research can be carried out on heterogeneous subjects between 3-15 people. Determination of the subject is done using a purposive sampling technique, which is determined based on certain criteria (Creswell, 2014). The subjects are the Qur'an memorizer with minimum memorization of $15 \mathrm{juz}$ (chapter) and has the status of a student before being interviewed. All the participants involved in this study were students at the Universitas Islam Negeri Sunan Kalijaga, Yogyakarta, Indonesia. The ten participants lived in male and female Islamic boarding schools in Yogyakarta. Six participants lived in a male-only Islamic boarding school and four participants lived in a female-only Islamic boarding school. The subjects were asked their willingness. This is done to make it easier for researchers to obtain data and information in research. Meanwhile, the detailed identity of the participants in this study can be shown in Table 1 below.

Table 1

Sources of research data

\begin{tabular}{llllll}
\hline \multirow{2}{*}{ Name } & \multirow{2}{*}{ Islamic Boarding School } & Age & Gender & Total \\
\cline { 5 - 6 } & & 22 & $\checkmark$ & Fale & 1 \\
\hline DR & Male Group & 21 & $\checkmark$ & & 1 \\
\hline AQ & Male Group & 22 & $\checkmark$ & - & 1 \\
\hline IZ & Male Group & 22 & $\checkmark$ & - & 1 \\
\hline L & Male Group & 20 & $\checkmark$ & - & 1 \\
\hline ZA & Male Group & 22 & $\checkmark$ & $\checkmark$ & 1 \\
\hline DS & Male Group & 20 & - & $\checkmark$ & 1 \\
\hline SF & Female Group & 20 & - & $\checkmark$ & 1 \\
\hline AZ & Female Group & 21 & - & $\checkmark$ & 1 \\
\hline H & Female Group & 19 & - & & 10 \\
\hline EH & Female Group & & & & 1 \\
\hline Total & & &
\end{tabular}

\section{Instruments and Procedures}

The instruments used in this study were interview and observation guidelines. The interview guide was used to reveal information about the motive for memorizing the Qur'an, how the Quran memorizer performs self-regulation, and whether there is any spiritual experience that the Qur'an reciter has experienced. Data collection was carried 
out according to appointments made between researchers and informants, some were conducted on campus, or informants came to the researchers' homes, or even at convenient places such as restaurants and cafes. Interviews for each participant were carried out for approximately 60 minutes. The interview activity stopped after getting a representative answer with the aim of this research related to the motives, self-regulation learning, and spiritual experience of the Qur'an memorizers.

Observations were used to determine the behavior of memorizing the Qur'an while in Islamic boarding schools. To obtain this data, the researcher was assisted by 3 research assistants. The assistants are students as well as students who live in the same Islamic boarding school as the research subject. The researcher asked the research assistants to observe the behavior of the Quran memorizers according to the checklist provided. The total data collection was 1.5 months. After 1.5 months, the researchers invited the assistants to collect their observations and at the same time clarify the results obtained. So, the presentation assistants are related to the data they collect. If anything is not clear, the researchers confirm directly with the research assistants.

\section{Data Analysis Technique}

The qualitative data analysis was carried out in eight stages. The first stage is doing things related to data, namely taking data, organizing data, sorting it into manageable units. The next step is to synthesize it, look for and find patterns, find what is important and what is learned, and decide what parts to share with others. The final stage is the validity of the research using a credibility test through triangulation techniques and a dependability test with an audit of the entire research process, both processes and results or outputs (Haberman, 2014).

\section{FINDINGS}

The following are the results of interviews with research subjects. From the results of this interview, the answers to the research questions were mapped, namely motives, selfregulation, and spiritual experiences of the Qur'an memorizer.

\section{Motives of the Qur'an Memorizer}

The motives for memorizing the Qur'an that was expressed by the informants were for the sake of their parents, seeking the pleasure of Allah, and to complete their mastery of knowledge. For the target of memorizing the Qur'an, there is a difference where students have a target of memorizing more in one day than students. Students can memorize up to five pages in one day.

"If on campus I can get at least 2 pages. Right here it should be 5 pages. So, 2 pages on campus, here 3 pages". (Informant Dr).

Students only target one rote face a day, even other students (AQ) have absolutely no target to memorize, just live it, he added.

"Yes, one face, at least. Yes, if you have already, already memorizing it is so easy. I've memorized it before, but it's still messy, bro, so it's over again". (AQ informant). 
In undergoing the process of memorizing the Qur'an, students and female students often face challenges and obstacles. This requires them to establish goals, carry out monitoring and evaluation, and consequently. There are two challenges and obstacles that students feel, namely those that come from themselves (internal) and those from outside (external). Among the obstacles and challenges that come from internally experienced by students are difficulty in dividing time (time management) and feeling lazy. Among the challenges faced by female students were feeling heavy because they were memorizing them again, experiencing boredom, and feeling lazy. Especially for the informant, Sf experienced obstacles because of his weak physical condition and was often sick.

The next challenge is from the outside (external). As for the external obstacles for students, including environmental conditions that are not conducive, there are the same verses when memorizing, and pocket money from parents who are not fluent. AQ informants have strategies to overcome problems related to unfavourable environmental conditions, namely first, running from the environment then moving to another place (mosque), and the second is improving the environment.

"Overcoming the environment, so there are two choices. First, we run from the environment. Second, we fix it, fix it. To what extent or how big are our levels to be able to influence them not to be lazy or what kind of role we have in that environment, for example, it is already significant above, it's easy to make songs with the community, so let's recite like that well, for example, we have those roles. well, that's what the head of the village uses, let us do the chanting and the chanting of the chanting and the chanting”. (Informant AQ).

Meanwhile, the external obstacles experienced by female students include feeling reluctant to other students whose status is not a Quran memorizer. The female students live in the same dormitory. Apart from facing the dormitory conditions that are not conducive to memorizing, they must follow activities that are already in dormitory. Female students also respond to environmental conditions that are less conducive by looking for other places that are considered more conducive to memorizing.

"If there is someone in the room, there are those who don't. Yes, if you do it on the clothesline or not on the top of the reservoir, or on the stairs where there are no people, the quiet one. So, the concentration can be more. Sometimes you can do it in the room too, it's just a little annoying because it's crowded". (Informant Az).

In facing every obstacle when memorizing the Al-Quran, the participants still recalled the initial motivation in memorizing the Qur'an. Each participant expressed their argument about their motivation to memorize the Al-Quran.

"Although in memorizing the Qur'an, I am faced with conditions that have various obstacles, I still intend to memorize the Qur'an correctly and many verses. I do this because I know that when I can memorize the Qur'an, Allah will surely give me grace and mercy". (Informant L). 
"I still memorize the Koran even though sometimes there are many verses or few verses that I can memorize. I still try to continue to memorize the Koran every day with the motivation of making my parents proud and being a person who follows the sunnah of the prophet Muhammad". (IZ informant).

\section{Self-Regulation of the Qur'an Memorizer}

There are two factors of support for informants in memorizing the Qur'an, namely internal and external factors. The internal factors of the students based on the results obtained by the researcher were then divided into two things, namely the strategy of memorizing the Qur'an and the strategy for keeping memorization. While the internal factors obtained by researchers from interviews are environmental factors.

The memorization methods used by students include the comb method (memorizing from behind) and memorizing by repeating each verse nine times to half a glass (half a page). Regarding the time chosen by the two students to memorize the Qur'an, it was different. IZ informants memorized after every Isha and finished Asr, while AQ informants memorized the Qur'an everyone hour before maghrib or around five o'clock in the afternoon and early morning. The two informants each had a certain time to memorize the Qur'an.

The internal factor which further motivated the informants to memorize the Qur'an was the use of strategies in keeping memorization. To maintain memorization, the two informants both used the mosque as a place for reciting. The mosque was chosen because the informant considered it less conducive in the mosque or complex. In addition, the two male informants took advantage of the time after memorizing deposits to maintain memorization with reciting.

"Recite runs out of deposits in the hall, sometimes it is low, around eight o'clock. Then if it's the holidays like this it is afternoon if not sleepy". (Informant IZ).

As for female students, according to Az's informants, use the time before the deposit time by using the relay memorization method. According to the informant, this method of memorizing the relay was memorizing a page and being listened to by his friend, then the friend took turns to continue memorizing, then the informant listened. This is done continuously until it is finished. The informant admitted that this method was more effective than having to memorize alone.

"My friend is as mirrored as I am my friend, that's my friend again, the relay is like that. It is more effective with my friends. So, we can see where we went wrong. So, for example, if the relay is like that, we can also concentrate on it. For example, what do you think about it? So, if the relay is more able to assess our memorization, you know" (Informant Az).

The female informants did not only take advantage of their fellow students from their previous boarding school because the three female informants (Dr, Sf, and Az) had previously lived in an Islamic boarding school in the neighbourhood where they lived and there, they also started memorizing the Qur'an. 
"I have an alumni community, miss. So, every week there used to be Khotmil (read the whole Qur'an) like that". (Informant Dr).

The informant Dr. has a method to keep his memorization, namely by repeating it in the morning, afternoon, and evening. Before rote deposit time.

"Taking care of it is hard. Sometimes we have arrived at the middle Juz (chapter), which at first, we forgot. Sometimes I take it in the morning when it is top, in the afternoon it is bottom-down. So later, guard, meet him in the middle. To repeat". (Informant Dr).

For the informant, Sf usually follows his friend's invitation to join the watch outside the hut. He also does this to maintain memorization, besides that he also evaluates every time he completes memorization deposits. SF also uses digital Quran application media to make it easier to memorize.

Students have a source of motivation to memorize the Qur'an in a balanced way between internal and external. The source of internal motivation to memorize the Qur'an is indicated, for example, in "seeking the pleasure of Allah, one's desire, and wanting to gain inner peace". The external sources of motivation are such as for the sake of parents, wanting to preserve family habits as Quran memorizers, and following friends' requests. For male students, internal motivation (such as obtaining the blessing of Allah, completing knowledge fans, wanting to achieve the virtue of memorizing the Qur'an) is more dominant than external motivation (motivated by the father and Sir Munawwir, for the sake of their parents).

Regarding the strategy of memorizing the Qur'an, there are differences between female and male students. Female students have a target of memorizing more than their male counterparts ( 5 sheets vs 1 sheet), involving friends, and using technology. Meanwhile, male students, in addition to having fewer memorization targets (at least one sheet a day), also use more repetitive methods and do not involve friends in memorizing.

In controlling memorization, female students did it more intensely, namely by evaluating the memorization after each deposit, while the sons evaluated it every 2 months. The female students mark the wrong part when memorizing while the sons repeat, recite, and avoid punishment for fear of being controlled by the Ustaz (teacher). Between sons and daughters have different ways in terms of managing memorization time and place to memorize. Female students use every spare time to memorize, while male students have certain times to memorize such as after Asr, before maghrib, after evening, and early morning. This shows that female students have more time to memorize than male students. If you experience boredom, the female students will go for refreshment until their minds feel calm or sometimes just force themselves; while the son will run away from that environment to get a better environment. This indicates that female students emphasize a cognitive approach while the sons emphasize a behavioristics approach.

\section{Spiritual Experiences of the Qur'an Memorizer}

When asked whether there was any spiritual experience the subject had while memorizing the Qur'an. Some of the subjects said "so-so" and some others said, "Yes, 
there is, it feels strange beyond expectations". This is reflected in the following interview excerpt,

"For me, the teachings of Islam are very logical. So, when I memorize the Qur'an, I feel calm, that is very natural because the entire universe, including the nerves of the brain, is subject to Allah, right? This means that when I get used to reciting (memorizing) verses of the Qur'an which are divine words, then my entire body and soul submits, so the effect is that I feel calm. But there are also unique experiences, for example when I have a wish, before going to bed I recite the verses of the Qur'an first, then go straight to sleep. Well, in that dream there must be an answer to my prayers. So, I think my dream is a hint of my prayer. And that I experienced several times (often)".

Another student revealed,

"There are strange things that I often experience while memorizing the Qur'an. For example, I must pay tuition fees, but I don't have money. Want to ask my mother, embarrassed. Then I prayed and intensified reading (memorizing) the Qur'an. Then suddenly I felt calm and sure that there would be a help. It happened repeatedly during my college days".

EH students shared their spiritual experiences while memorizing the Qur'an,

"My family doesn't have one, but my desire to go to college is very high. At that time, I asked Allah that I hope there was a way out, I did memorize the Qur'an. My father is in a small convection business. My father distributed his convection to the Surabaya and Jakarta areas. Since I was in college, my father's business has been running smoothly, almost perfect, especially when I had to pay tuition fees. Some surprises are an intermediary so that my father can pay my tuition fees. This lasted during my college. As soon as my college was over, suddenly my father's business died, my father's relationships in Surabaya and Jakarta no longer accepted my father's convection for various reasons, and after I finished college, my father was summoned to him".

Based on the results of the interview above, we summarize the motives, self-regulation, as well as spiritual experience of memorizing the Qur'an as shown in Table 2 below. 
Table 2

Motives, self-regulation, and spiritual experience of memorizing the Qur'an

\begin{tabular}{|c|c|c|c|c|}
\hline \multirow[b]{2}{*}{ No. } & \multirow[b]{2}{*}{ Participants' Answers } & \multicolumn{3}{|l|}{ Analysis } \\
\hline & & $\begin{array}{l}\text { Variables (Motives, Self- } \\
\text { regulation, Spiritual } \\
\text { experience) }\end{array}$ & Aspect/Source & Total \\
\hline 1. & Feel happy and calm & $\begin{array}{l}\text { Motives and Spiritual } \\
\text { Experiences }\end{array}$ & $\begin{array}{l}\text { Self-Rewarding and } \\
\text { Internal }\end{array}$ & 5 \\
\hline 2. & Obtain the highest scientific degree & Motives & Internal & 10 \\
\hline 3. & Sharpen your memorization skills & Motives & $\begin{array}{l}\text { Cognitive Functioning } \\
\text { and Internal }\end{array}$ & 1 \\
\hline 4. & $\begin{array}{l}\text { The obligation of Muslims (fardhu kifayah) as a } \\
\text { way to preserve the Qur'an }\end{array}$ & Motives & $\begin{array}{l}\text { Ethics or morals right } \\
\text { and Internal }\end{array}$ & 6 \\
\hline 5. & Feeling interested in memorizing & Motives & Interests and Internal & 10 \\
\hline 6. & Deepening the science of religion & Motives & $\begin{array}{l}\text { Expectations and } \\
\text { Internal }\end{array}$ & 10 \\
\hline 7. & $\begin{array}{l}\text { As a household investment (in solving life } \\
\text { problems) }\end{array}$ & Motives & $\begin{array}{l}\text { Expectations and } \\
\text { Internal }\end{array}$ & 2 \\
\hline 8. & Inspired by the kindness of parents & Motives & Values and Internal & 2 \\
\hline 9. & $\begin{array}{l}\text { Believing as a way to preserve the purity of the } \\
\text { Qur'an }\end{array}$ & Motives & $\begin{array}{l}\text { Expectations and } \\
\text { Internal }\end{array}$ & 10 \\
\hline 10. & Get the approval of parents & Motives & Values and Internal & 4 \\
\hline 11. & Memorizing the Quran raises parents to heaven & Motives & Attribution and Internal & 9 \\
\hline 12. & $\begin{array}{l}\text { Memorizing the Qur'an makes the reciting teacher } \\
\text { proud }\end{array}$ & Motives & Attribution and Internal & 4 \\
\hline 13. & Memorizing the Qur'an makes parents happy & $\begin{array}{l}\text { Motives and Spiritual } \\
\text { Experiences }\end{array}$ & Attribution and Internal & 8 \\
\hline 14. & $\begin{array}{l}\text { Inspired by the kindness of parents who are also a } \\
\text { hafizh }\end{array}$ & Motives & Model and External & 4 \\
\hline 15. & Education entry provisions without tests & $\begin{array}{l}\text { Motives and Spiritual } \\
\text { Experiences }\end{array}$ & $\begin{array}{l}\text { Achievements and } \\
\text { Externals }\end{array}$ & 4 \\
\hline 16. & To get a special gift from parents & Motives & Gifts and Externals & 2 \\
\hline 17. & The provision to meet the children of the clergy & Motives & $\begin{array}{l}\text { Recognition and } \\
\text { Externals }\end{array}$ & 2 \\
\hline 18. & Investing in family life & Motives & Externals & 8 \\
\hline 19. & Investment in the afterlife & Motives & Externals & 8 \\
\hline 20. & $\begin{array}{l}\text { When bad mood, establish the intention/purpose of } \\
\text { memorizing the Qur'an }\end{array}$ & Self-Regulation & - & 5 \\
\hline 21. & Create goals (daily, weekly and monthly) & Self-Regulation & - & 7 \\
\hline 22. & Using methods according to time and conditions & Self-Regulation & - & 6 \\
\hline 23. & Looking for a comfortable place & Self-Regulation & - & 6 \\
\hline 24. & Have a memorizing strategy & Self-Regulation & - & 5 \\
\hline 25. & dreamed in answer to my prayers & Spiritual Experiences & - & 6 \\
\hline 26. & Flowing financial and moral assistance & Spiritual Experiences & - & 8 \\
\hline
\end{tabular}

Based on Table 2, it can be seen that the motives of the subject to memorize the Qur'an are mostly internal (13 motives) than external (3 motives), with the most motives as follows. Its intrinsic motives include a keen interest in memorizing the Qur'an, b) a strong desire to deepen the knowledge of religion, c) belief it is a way to increase the degree of scholarship, and d) believe it is a way of preserving the Qur'an. The extrinsic motives include being inspired by the good behaviour of parents as a hafizh (memorizer of the Qur'an), b) investing in family life, d) investing in the afterlife, and e) solutions to life problems.

Self-regulation carried out by memorizing the Qur'an in this study includes strengthening the intention to memorize the Qur'an, b) understanding the stages of 
tahfizh (memorizing the Qur'an), c) setting targets per day, d) choosing the ideal time to memorize the Qur'an, d) choosing a comfortable place to memorize, and e) have a memorizing strategy. The spiritual experiences of hafizh (memorizer of the Qur'an) include feeling calm, b) getting help during difficulties, especially in completing college assignments, c) feeling awake, and d) feeling peaceful.

\section{DISCUSSION}

Motivation is the reason or basis for all one's actions in learning activities. Motivation in learning based on self-regulation is manifested in the form of making decisions to participate (Zimmerman \& Martinez-Pons, 1990). The decision of the students to memorize the Qur'an shows that they have a strong motivation or motivation to memorize the Qur'an. The results of this study have various benefits for both the AlQuran memorizers and students who are currently studying. This study focuses on three components that affect the ability of the Al-Quran memorizers. The three components studied in this study include motivation, self-regulated skills, and spiritual experience, all three of which are still rarely studied. Every individual to achieve more easily something high achievement requires a strong motivation in him. The motivation can arise from within or from outside the individual. Especially if the motivation that arises is not merely pursuing world achievements, but the motivation to get a reward or blessing from God. The desired achievement can certainly be easily achieved and more meaningful. After having a strong motivation, everyone also needs independence in himself. This independence needs to be managed systematically wherever and under any conditions. This is done so that the target to get high achievement can be realized even though many obstacles stand in the way. Control of emotions and time needs to be done as well as possible so that there are no losses but gains that come. In addition, achieving high achievements must be accompanied by a high spirituality approach to be able to face every winding test and to be more grateful for what has been obtained.

The results showed that students have internal and external motivation to memorize the Qur'an. The internal motivation of the Qur'an memorizers such as egoist, wanting to enrich knowledge and seeking peace of mind; while external motivation is for the sake of parents, keeping family habits, following friend requests. This is as stated by Syah (2010) that there are two motives for a person to do something, namely internal and external motivation. Syah views that internal motivation is better than external motivation. This is due to its nature in which internal motivation is more lasting than external motivation. Internal motivation is not easily swayed, while external motivation is easily shaken, which means that when the one pushing something is lost, someone will automatically stop doing something he is doing (Syah, 2010). In this case, if the motivation of the students is for the sake of their parents, then when their parents are not there (for example, they die) it will make the students no longer or reduce their enthusiasm for memorizing the Qur'an. However, unlike the Shah, Alsa revealed that there is no need to care about the source of motivation, the most important thing is the intensity of the motivation. Both internal and external motivation, if the intensity is strong then it becomes very important to make someone move or do something (Alsa, 2010). 
Some researchers use a trait perspective, suggesting that motivation often involves relatively long-lasting personality characteristics of people to a greater or lesser extent. Other researchers use a behaviorist approach that focuses on the consequences (either reinforcing or punishing) that various behaviours may bring. Some researchers use a social cognitive perspective or cognitive perspective, which focuses on self-perception and other cognitive factors that directly or indirectly encourage a person to engage in certain behaviours and no other behaviours (Ormrod et al., 2006). Measurement of a person's motivation can be carried out based on several indicators such as duration of activities, frequency of activities, persistence in activities (fortitude, persistence, and ability to face obstacles and difficulties), devotion and sacrifice to achieve goals, level of aspirations to be achieved with the activities carried out, level achievement or product qualification (output) achieved from the activities carried out, and the direction of attitudes towards the activity objectives

Several experts use the term learning methods to show learning strategies in learning based on self-regulation. The task requirement of the method dimension is to choose the right method to improve the quality of learning (Elliot, 2009; Listiana, 2020). The selfregulation attribute of the method component is the occurrence of hafizh (memorizer of the Qur'an) behaviour which is planned and automated. It is said to be planned because the behaviour of hafizh (memorizer of the Qur'an) students who carry out learning based on self-regulation has clear goals and self-awareness. It is said to be automated because the use of learning methods that are appropriate and done repeatedly has become a habit for him. Cognitive learning strategies in self-regulation-based learning include rehearsing, elaborating, modelling, and organizing (Howard-Rose \& Winne, 1993; Supriyadi \& Julia, 2019). In the use of memorization strategies, because female students have more targets to memorize than males, the strategies used are more varied (not just repeating or memorizing) than males (Hoque, 2018).

The students of hafizh (memorizer of the Qur'an) have used various ways to memorize the Qur'an, especially by repeating it. Repetition is a method that is often used by someone as a form of exercise. As Anderson stated that rehearsal is a process of repeating information to help remember information (Anderson, 2000). According to the information processing model, individuals remember and store information through several stages (Anderson, 2000). The process of entering this information starts from the senses (eyes, ears, skin, and other senses). After the senses receive information, the information is passed into cognitive processes. In the cognitive process, the information enters the short-term information store (STS) and then the information enters the longterm information store (LTS). In the process, not all information can enter the LTS, a lot of information is lost during the process of entering the LTS. The rehearsal process is carried out before information enters long-term memory (LTS) (McCown, 1999).

To control the memorization that has been obtained, students hafizh (memorizer of the Qur'an) involves friends to listen and do it in a more intense time (after each deposit), and others carry out evaluation or control memorization every two months after rote deposits to avoid punishment from the Ustaz (teacher). Memorization control that is carried out by hafizh (memorizer of the Qur'an) students is a must in learning based on self-regulation. This is as stated by Zimmerman \& Martinez-Pons that someone who 
learns based on self-regulation has an awareness of the results of their performance (Woolfolk, 2008). Meichenbaum calls this metacognition, which is a person's awareness of their cognitive machines and how these machines work (Meichanbaum et al., 1985).

Metacognition involves two things, namely knowledge, and metacognitive regulation. Metacognition knowledge refers to a person's knowledge of their cognitive abilities. Metacognitive knowledge is a high level of cognition that is used to monitor and regulate cognitive processes such as reasoning, problem-solving understanding, and learning (Metcalfe \& Shimamura, 1994; Sawuwu \& Partana, 2018). Everyone has different abilities in terms of knowledge and metacognitive skills. Therefore, they also differ in how well and how fast they learn (Oppong et al., 2019). Metacognitive knowledge consists of three sub-knowledge that facilitate the reflection aspects of metacognition, namely declarative knowledge (knowledge about oneself as a student, factors that affect a person's learning and memory. As well as the skills, strategies, and resources needed to do a task-know what to do), procedural knowledge (knowledge of how to use strategies), and conditional knowledge (knowledge of when and why a strategy was used). Metacognitive knowledge develops with increasing age and experience, which is relatively stable.

Metacognitive regulation is concerned with self-regulatory mechanisms. Metacognitive regulation includes several sub-processes that facilitate control aspects of learning such as planning, monitoring, and assessing a person's use in learning activities. Metacognitive regulation, in other words, applies metacognitive knowledge that is used to regulate thinking and learning (Stephanou \& Mpiontini, 2017). The basic skills that are carried out, in this case, include planning, monitoring, and evaluating. Planning has to do with deciding how much time to give a task, which strategy to use, how to start with it, what resources to use, what order to follow, which ones to give cursory attention to, and which to give full attention. Monitoring is real-time awareness of how I work or asking yourself, does this make sense? am I working too fast?. Evaluating, namely making judgments about the process and results of thinking and learning. In this regard, the questions that need to be addressed include, should I change my strategy? Do I need to seek help or give up right now? and so on. In contrast to the nature of cognitive knowledge, the nature of metacognitive regulation is less stable, depending on the characteristics of students and the course material or the character of the task at hand (Seufert, 2018).

The female students often use their spare time to memorize, while the sons only use certain times. If you feel bored, the female students do a refreshing first while the sons avoid the environment, they think is not conducive. This shows that the hafizh (memorizer of the Qur'an) has a sensitivity to the environment around where they memorize the Qur'an. This is in line with what Zimmerman stated that a person who learns based on self-regulation has a sensitivity to the social environment and the resources around him. Zimmerman uses the term 'resourcefulness' which refers to the ability to control the physical environment around it in terms of limiting distractions that interfere with learning and to successfully search for and use the references and skills needed to master what is learned (Zimmerman \& Martinez-Pons, 1990). Resourcefulness is characterized by a person's activeness in seeking information, 
organizing the environment, and minimizing distractors. Forms of self-regulatory processes related to the environmental dimension are environmental structuring and help-seeking. Structuring the environment is concerned with creating a learning environment that can support the implementation of learning activities optimally.

Furthermore, the memorizers of the Qur'an continue to memorize the Qur'an because they get a spiritual experience that is not obtained by non- memorizers of the Qur'an. The memorizers of the Qur'an after memorizing the Qur'an have a calm heart in them. In addition, they are also wiser in dealing with any problems that occur in their lives. Every individual who has been able to memorize and practice the contents of the Qur'an will be more likely to surrender every affair of life to Allah (Arat, 2020). The memorizers of the Qur'an also have a stronger spiritual control ability if they are tempted to do things that are forbidden by religion. In addition, the memorization of the Qur'an is also easier to launch when facing every problem. This is natural considering that the memorizers of the Qur'an are closer to Allah, the creator of all things. However, nowadays every individual is far from even forgetting the word and existence of God. Some individuals are more concerned with worldly matters and think that God does not exist (Kahane, 2011). Therefore, there needs to be awareness in every individual to keep in mind the existence of God that God is the one who created everything and because of God humans exist on earth. One effort that can be done is by memorizing the Qur'an as the word of God.

\section{CONCLUSION}

Based on the description of the research findings, it can be concluded that the subject of this study has a stronger internal motive for memorizing the Qur'an than an external motive. It is evident from the many internal motives put forward by the research subjects. Self-regulation carried out by memorizing the Qur'an in this study includes establishing the purpose (intention) of memorizing the Qur'an, monitoring and evaluating, as well as being consequent on the choice to memorize the Qur'an by having a strategy in keeping the Qur'an memorizing. The spiritual experiences of the Quran memorizers include feeling calm, getting help during difficulties, especially in completing college assignments, feeling awake, and feeling at peace.

\section{RECOMMENDATION}

Based on the results obtained in this study, several suggestions can be made. For hafizh (memorizer of the Qur'an) students, they can improve their memorization of the Qur'an by developing self-regulation in learning to memorize the Qur'an. The development of good self-regulation can also recognize self-efficacy so that it can reduce and face obstacles in memorizing such as boredom, boredom, and others. For Ustaz (teacher) be more intense in monitoring so that hafizh (memorizer of the Qur'an) have better memorization quality. For policyholders at Islamic boarding schools appreciate the hafizh (memorizer of the Qur'an) more for memorizing the Qur'an because not all students have an interest in becoming hafizh (memorizer of the Qur'an) through the provision of adequate facilities and infrastructure, giving rewards, using technology, and so on. For the next researcher can use different methods with this research such as 
experimental methods, case studies, and others; or by involving other variables such as culture, personality, and religiosity.

\section{LIMITATIONS}

This research certainly still has many limitations. Research subjects and strategies used in memorizing the Qur'an can be developed further and deeper. Besides, the types of research that are more diverse and stronger will certainly strengthen the results of subsequent research.

\section{REFERENCES}

Ahsin, W. Al-Hafidz. (1994). Bimbingan Praktis Menghafal Qur'an [Practical Guidance on Memorizing the Qur'an]. Bumi Aksara.

Ainisyifa, H., \& Amelia, R. (2018). The effect of family literacy culture on student's motivation in Islamic education subject at state senior high school in Garut. Journal of Islamic Education UIN Sunan Gunung Djati/Jurnal Pendidikan Islam UIN Sunan Gunung Djati, 4(2), 12-24.

Albar, M. K., \& Yuliana, Y. (2021). Self-regulation of Qur'an memorizers in Pesantren Salaf in the millennial era (A phenomenological Study at Pesantren Al-Hidayah Karangsuci Purwokerto). Psychology and Education Journal, 58(2), 7205-7212.

Ali, M. M. (2011). Holy Quran. Ahmadiyya Anjuman Ishaat Islam Lahore USA.

Anderson, J. R. (2000). Learning and memory: An integrated approach. John Wiley \& Sons Inc.

Arat, Z. F. K. (2020). Economic Rights and Justice in the Qur'an. Human Rights Quarterly, 42(1), 85-118.

Bilewicz, M., Witkowska, M., Stefaniak, A., \& Imhoff, R. (2017). The lay historian explains intergroup behavior: Examining the role of identification and cognitive structuring in ethnocentric historical attributions. Memory Studies, 10(3), 310-322.

Creswell, J. W. (2014). A concise introduction to mixed methods research. SAGE publications.

Haberman, S. J. (2014). Analysis of qualitative data: Introductory topics. Academic Press.

Hoque, E. (2018). Memorization: a proven method of learning. International Journal of Applied Research, 22(3), 142-150.

Hommel, B., \& Wiers, R. W. (2017). Towards a unitary approach to human action control. Trends in Cognitive Sciences, 21(12), 940-949.

Howard-Rose, D., \& Winne, P. H. (1993). Measuring component and sets of cognitive processes in self-regulated learning. Journal of Educational Psychology, 85(4), 591-606.

Huda, M., Sudrajat, A., Muhamat, R., Teh, K. S. M., \& Jalal, B. (2019). Strengthening divine values for self-regulation in religiosity: insights from Tawakkul (trust in God). International Journal of Ethics and Systems, 8(1), 178-184. 
Kahane, G. (2011). Should we want God to exist?. Philosophy and Phenomenological Research, 82(3), 674-696.

Khafidah, W., Wildanizar, W., Tabrani, Z. A., Nurhayati, N., \& Raden, Z. (2020). The application of Wahdah method in memorizing the Qur'an for students of SMPN 1 Unggul Sukamakmur. International Journal of Islamic Educational Psychology, 1(1), 37-49.

Kibtiyah, M., Suud, F. M., Masruri, S., \& Bashori, K. (2020). Self-regulated learning of Islam to help shape the habit of memorizing Al-Qur'an. PalArch's Journal of Archaeology of Egypt/Egyptology, 17(6), 9144-9143.

Latipah, E., \& Kamsyach, A. (2017). Psikologi dasar [Basic psychology]. PT Remaja Rosdakarya.

Lepper, M. R., Corpus, J. H., \& Iyengar, S. S. (2005). Intrinsic and extrinsic motivational orientations in the classroom: Age differences and academic correlates. Journal of Educational Psychology, 97(2), 184-189.

Lin, J. W. (2018). Effects of an online team project-based learning environment with group awareness and peer evaluation on socially shared regulation of learning and selfregulated learning. Behaviour \& Information Technology, 37(5), 445-461.

Listiana, L. (2020). Enhancing self-regulation skills through group investigation integrated with think talk write. International Journal of Instruction, 13(1), 915-930.

McCown, R. R. (1999). Educational psychology: A learning-centered approach to classroom practice. Scarborough, Ont.: Allyn \& Bacon Canada.

Meichanbaum, D., Burland, S., Gruson, L., \& Cameron, R. (1985). Metacognitive assessment: The growth of reflection in children. Academic Press.

Metcalfe, J., \& Shimamura, A. P. (1994). Metacognition: Knowing about knowing. MIT press.

Mietzner, M., \& Muhtadi, B. (2018). Explaining the 2016 Islamist mobilization in Indonesia: Religious intolerance, militant groups, and the politics of accommodation. Asian Studies Review, 42(3), 479-497.

Nigg, J. T. (2017). Annual research review: On the relations among self-regulation, self-control, executive functioning, effortful control, cognitive control, impulsivity, risk-taking, and inhibition for developmental psychopathology. Journal of Child Psychology and Psychiatry, 58(4), 361-383.

Oppong, E., Shore, B. M., \& Muis, K. R. (2019). Clarifying the connections among giftedness, metacognition, self-regulation, and self-regulated learning: Implications for theory and practice. Gifted child quarterly, 63(2), 102-119.

Oppong, E., Shore, B. M., \& Muis, K. R. (2019). Clarifying the connections among giftedness, metacognition, self-regulation, and self-regulated learning: Implications for theory and practice. Gifted Child Quarterly, 63(2), 102-119.

Ormrod, J. E., Anderman, E. M., \& Anderman, L. H. (2006). Educational psychology: Developing learners. Prentice-Hall, Inc. 
Passer, M. W., \& Smith, R. E. (2004). Psychology: The science of mind and behavior. McGraw-Hill.

Quraish, S. (1994). Membumikan al-Qur'an [Grounding the Qur'an]. Mizan.

Santrock, J. W. (2017). Educational psychology. McGraw-Hill Education.

Sawuwu, B. Y., \& Partana, C. F. (2018). Exploring metacognitive judgment of chemistry teacher candidates on chemical reading activity. International Journal of Instruction, 11(4), 75-92.

Seufert, T. (2018). The interplay between self-regulation in learning and cognitive load. Educational Research Review, 24(1), 116-129.

Slavin, R. E., Lake, C., Chambers, B., Cheung, A., \& Davis, S. (2009). Effective reading programs for the elementary grades: A best-evidence synthesis. Review of Educational Research, 79(4), 1391-1466.

Stephanou, G., \& Mpiontini, M. H. (2017). Metacognitive knowledge and metacognitive regulation in self-regulatory learning style, and in its effects on performance expectation and subsequent performance across diverse school subjects. Psychology, 8(12), 19411948.

Supriyadi, T., \& Julia, J. (2019). The problem of students in reading the Quran: A reflective-critical treatment through action research. International Journal of Instruction, 12(1), 311-326.

Syah, M. (2010). Psikologi pendidikan dengan pendekatan baru [Educational psychology with a new approach]. Rosdakarya.

Underwood, L. G., \& Teresi, J. A. (2002). The daily spiritual experience scale: Development, theoretical description, reliability, exploratory factor analysis, and preliminary construct validity using health-related data. Annals of Behavioral Medicine, 24(1), 22-33.

Wang, M., Guo, T., Ni, Y., Shang, S., \& Tang, Z. (2019). The effect of spiritual leadership on employee effectiveness: An intrinsic motivation perspective. Frontiers in Psychology, 9(1), 2627-2635.

Wolters, C. A., Pintrich, P. R., \& Karabenick, S. A. (2005). Assessing academic selfregulated learning. In What do children need to flourish? (pp. 251-270). Springer, Boston, MA.

Woolfolk, A. (2008). Educational psychology active learning edition-tenth edition. Allyn \& Bacon.

Zimmerman, B. J., \& Martinez-Pons, M. (1990). Student differences in self-regulated learning: Relating grade, sex, and giftedness to self-efficacy and strategy use. Journal of Educational Psychology, 82(1), 51-59. 